\title{
Application of Project Management Process on Environmental Management System Improvement in Mining-Energy Complexes
}

\author{
Jelena Malenović Nikolić ${ }^{1, *}$, Dejan Vasović ${ }^{1}$, Ivana Filipović ${ }^{2}$, Stevan Mušicki ${ }^{3}$ \\ and Ivica Ristović ${ }^{2}$ \\ 1 Faculty of Occupational Safety in Niš, University of Niš, Čarnojevića 10a, 18000 Niš, Serbia; \\ dejan.vasovic@znrfak.ni.ac.rs \\ 2 Faculty of Mining and Geology, University of Belgrade, Đušina 7, 11000 Belgrade, Serbia; \\ ivana.filipovic@rgf.rs (I.F.); ivica.ristovic@rgf.bg.ac.rs (I.R.) \\ 3 Military Academy, University of Defence, Pavla Jurišića Šturma Street 33, 11000 Belgrade, Serbia; \\ mustmilenko@yahoo.com \\ * Correspondence: malenovicfznr@gmail.com; Tel.: +381-631-042-468 \\ Academic Editor: Ivica Ristovic \\ Received: 31 May 2016; Accepted: 29 November 2016; Published: 16 December 2016
}

\begin{abstract}
Aims and background: Mining and energy complexes in Serbia are recognized as a major source of a large number of pollutants. Serbia's environmental performance reports clearly indicate that large mining and energy complexes are the dominant source of air pollution. It is difficult to determine which of them remarkably threaten the quality of the environment, as all the basic elements of the environment (air, water, and soil) are threatened, not just one. Mining and energy complexes significantly reduce the quality of the immediate environment, as the distance areas throughout water and air pollution propagation. Additional motivation for this study lies in the fact that large mining and energy complexes are particularly interesting because they are located in the immediate vicinity or large rivers (mostly the Danube), which are protected in many national and international legislation acts (particularly the Danube). The basis for the preservation of environmental quality is an effective environmental management system (EMS) in mining and energy complexes. The aim of this study is to promote and elaborate the possibility for improving the mining and energy complex environmental protection/management system by applying the basic principles of sustainable development. Methodology: Project management methodology is selected as a tool. Project management is based on the application of a network planning technique (Critical Path Method), because of its suitability for representing the logical structure of environmental protection system. The survey was conducted in the area of the city of Kostolac. The examined area included mining and energy complexes in Kostolac, which incorporate three surface mines (Ćirikovac, Klenovik, and Drmno) and two thermal power stations (TE "Kostolac A" (100 MW) and TE "Kostolac B" $(2 \times 348.5$ MW)). The PSR model (Pressures, State, Response) was used for the organization of the interactions within "society-environment" system as the basis for indicator selection. Results: Procedures to identify and determine the significance of the environmental aspects should be established by executive staff in mining and energy plants and complexes. Identification of environmental aspects is the first part of the planning system of environmental management and the activities related to them. The accomplishment of critical path activities represents the basis for improving the environmental protection system in mining and energy complexes. Discussion: Application of sustainable development principles depends on the country's energy potential and the application of the adopted environmental policy regarding mining and energy complexes. Strict enforcement of existing laws and regulations presents an opportunity to rectify many shortcomings while providing economic benefits, restoring the usable value of ravaged land, and preserving air and water quality.
\end{abstract}


Keywords: management; mining and energy complexes; environment; sustainable development; network planning

\section{Introduction}

Mining and energy complexes represent significant sources of air, water, and soil pollution, through technological processes from coal excavation to ash disposal. The consequences for environmental quality are related to temporary or permanent destruction of agricultural land, deterioration of air quality, and discharge of untreated wastewater. Daily challenges come with the depletion of economically recoverable coal reserves; desolated areas; the destruction of humus layer; a change in pedological and geological composition; disturbance of soil stability; land subsidence; disposal of tailings, ash, and slag; and delivery of coal dust and ash through airflow and gas emissions from coal combustion. Wastewaters in the abandoned surface mines and deep mines lead to pollution of the surrounding land and the absence of flora and fauna in river beds. Flushing of mine slopes is a source of wastewater with high content of heavy metals.

As a contemporary trend, perhaps still not sufficiently recognized, risk-based approach to environmental management could be usefully applied to the issue of aspects ranking and its prioritization. Within this approach, the significance of the environmental aspects (and its impacts) is defined based on the total score of the mathematical product between the degree of impact significance and the likelihood of occurrence, according to the defined criteria.

The environmental impacts assessment consists of:

- environmental basis;

- $\quad$ potential impacts prediction;

- mitigation measures; and

- monitoring risk-based approach to environmental management rely on consideration of;

- hazard identification (in sense of likelihood);

- $\quad$ exposure assessment (in sense of importance); and

- risk characterization.

Risk, viewed in terms of consequences of operational activities of mining and energy complexes, is analyzed based on the function of probability of a risk event and the measurement of potential degradation of environmental quality. Risk events, i.e., operational activities that could affect the degradation of air, water, or soil quality, were determined based on the analysis of each stage of the technological processes of coal mining and combustion. Successful functioning of the risk management process, which is based on risk management (RM), total risk management (TRM), integrated risk management (IRM), enterprise risk management (ERM), and overall risk management, is a prerequisite for the development of modern mining and energy complexes, for the purpose of developing a systems process of environmental quality management.

No less important is the fact that by applying for international projects regarding environmental protection, mining and energy complexes management representatives actually begin preparations for implementing up-to-date technologies and harmonization of domestic laws and technical regulations with international ones. Creating conditions for compliance with international legal requirements is necessary when planning of international cooperation and implementation of European regulations, agreements, conventions, and recommendations is concerned. International conventions and recommendations that are relevant for mining, energy industry, and the environment should be considered as part of the preparation for potential European integration (with particular regard to the EU accession process and obligations that arise from the Chapter 27: Environment), but also as a requirement for improving the environmental policy of mining and energy complexes and public 
relations [1]. Adjustment of the environmental management system in accordance with Chapter 27 requirements leads to comprehensive harmonization of existing environmental protection practice.

\section{Indicators of Sustainable Development and Their Application in the Energy Sector}

Improving the environmental management system in the energy complex contributes to increased efficiency of completing the adopted environmental objectives and basic principles of sustainable development [2]. Regular monitoring of air, water, and soil quality enables timely response and prevention of hazardous events [3]. Alignment of production and consumption with the available natural resources plays a significant role in creating the basis for harmonious relations between the energy sector and sustainable development [4]. The concept of sustainable development of the environment and society was popularized in the Brundtland Report when it was published in 1987 [5]. In this report, sustainable social activities are defined as those that meet the needs of present generations without compromising the ability of future generations to meet their needs. Brundtland definition of sustainable development implies equal distribution of resources, not only spatially between users in a certain period, but also temporally between different generations of users over time. The idea is that resources are used in such a way that they have adequate availability for all generations, without any fear that some future generation will be worse off than the present generation-in terms of the capacity of the environment to support the development of society with its resources, and also to accept the influences of society, i.e., to absorb pollution [5].

The concept of sustainable development, adopted in 1992 in Rio de Janeiro, represents the forefront of environmental quality. It is based on the assessment of adverse impacts in order to avoid: irrational use of energy and raw materials, introduction of pollutants into the environment, and the disturbance of biodiversity [6].

Energy efficiency and exhaust fumes are indicators of the state of the environment, defined by a set of world development indicators, which include:

- real GDP per unit of energy consumption;

- net energy imports as a percentage of commercial energy consumption; and

- $\quad$ total carbon dioxide emissions per capita and per real GDP unit [7].

The principles of sustainable development represent a starting point for proposal of measures in order to preserve and improve environmental quality, those suitable for the field of energy transformation. According to the above-mentioned proposals, and customized to the energy-ecological problems, one should:

- examine and assess the adverse effects of the energy transformation on the environment;

- anticipate environmental risks;

- eliminate the causes of threats to the environment;

- establish an ethical attitude towards the environment and make rational use of natural resources;

- develop ecological ethics; and

- develop a consumer behavior, i.e., take into account the impact of the transformation of energy on the environment.

Consistent application of monitoring the interactions in "society-environment" system, whether it is on supervisory, operational, or research level, intermittent or continuous, results in a significant amount of graphical and numerical data. There are several methodological frameworks by which the data obtained through monitoring the environment are organized. The purpose of data organization is to create meaningful units on a higher hierarchy level, which indicate the specificities of interactions within the "society-environment" system and which are not sufficiently determined by traditional indicators [8]. It is essential that all approaches involve defining data-information category that is of neutral character and gets its meaning in relation to the indicator, which is necessarily meaningful information that is determined by the context of its application [9]. 
PSR (pressures, state, response): Pressures (on the environment), State (of the environment) Response (primarily from the society to the state and impacts) model was developed during the 1970s for the purpose of organizing data in the field of the environment of Canada, and it eventually began to be used in the practice of OECD, in the working group for the state of the environment [10]. The PSR model is a concept by which anthropogenic activities generate environmental pressures that result in changes in the state of environmental elements' quality. The society reacts in different ways to the observed changes in the state of environmental elements' quality, ranging from changes in nature and intensity of the pressures generated to the application of different plans for protection and improvement of environmental quality. Usability of the PSR model has been recognized on a global level, as it can be applied at supranational, national, regional, or local level [11]. Table 1 shows the indicators of causes, conditions, and responses, defined on the basis of the most important sources of environmental pollution as part of the work process in mining and energy complexes [8].

Table 1. Indicators of coal consumption.

\begin{tabular}{clll}
\hline Topic & \multicolumn{1}{c}{ Indicator of Causes } & \multicolumn{1}{c}{ Indicator of Conditions } & \multicolumn{1}{c}{ Indicators of Response } \\
\hline Energy use & $\begin{array}{l}\text { Level of annual coal exploitation } \\
\text { Convert primary coal energy into } \\
\text { secondary energy }\end{array}$ & $\begin{array}{l}\text { Share of lignite use compared } \\
\text { to other types of coal }\end{array}$ & $\begin{array}{l}\text { Rational consumption of coal reserves } \\
\text { Ese of alternative energy sources and } \\
\text { better types of coal }\end{array}$ \\
\hline
\end{tabular}

Measures to be taken in order to mitigate the impact of surface mining, preserve the quality of the environment, and achieve sustainable development principles include indicators of response; indicators of causes represent the environmental consequences of mining and energy complex operations; and indicators of conditions are related to environmental quality [7].

The principle of sustainable development affirmed by the Bergen Declaration, which was adopted by the Federal Ministry for Development, Science and the Environment and which can be applied in the energy sector, includes [2,6]: understanding and assessment of possible adverse effects (the precautionary principle), risk prediction, elimination of causes for threats to the environment (applying adequate technical and technological measures), ethical relationship of man (new appreciation for the environment), active protection of the environment (changing behavior), and new consumer style (changing consumption patterns).

Managing the process of action planning to prevent negative consequences, assessment of adverse effects, and reduction of excessive consumption of natural resources contribute to the preservation of environmental quality, compliance with applicable regulations, and approximation to European standards [11]. Analysis of the impact of work activities in mining and energy complexes and risk prediction are the basis for establishing sustainable development principles [12]. The goal is to enable the transformation of coal energy with less environmental degradation through moderate development and preservation of natural resources [13]. Environmental and economic benefits of respecting the principle of sustainable development are reflected in the rational exploitation of natural resources, preservation of the soil humus layer, and rehabilitation of degraded soils [14].

In order to reduce emissions of particulate matter, electrostatic filters in block B1 in TPP "Kostolac B" were reconstructed. In the thermal power plant "Kostolac B", in blocks B1 and B2, the final phase of flue gas desulfurization plant construction is in progress, with the aim to reduce emissions of sulfur and nitrogen oxide below $200 \mathrm{mg} / \mathrm{Nm}^{3}$ [15-17]. Preparations have started for the construction of facilities for wastewater treatment. The Investment-technical documentation and Feasibility Study is being prepared, with the preliminary design for construction of wastewater treatment plant "Kostolac B", for blocks B1, B2, and future block B3 with $350 \mathrm{MW}$ of power [15].

In the area of soil protection in the TPP "Kostolac A", the current project is "Replacement of the system for ash and slag transport in TPP Kostolac A" [15]. There is also some work on the current affairs in recultivation of mining area dumps and disposal of tailings in the mining and energy complex. 
Based on the data from the National Registry of pollution sources in 2012, 2013 and 2014, which are presented in the Report on the environmental situation in the Republic of Serbia, Ministry of Energy, Development and Environmental Protection of the Republic of Serbia, a comparative view of the values of emitted pollutants was discussed [16]. Based on the graphic display, it can be concluded that twenty dominant sources of air pollution in the Republic of Serbia are concentrated in the northern and central part of the country. Thermal power plant "Kostolac A" and "Kostolac B" are in the third and fourth place according to the emission levels of sulfur oxides. Thermal power plant "Kostolac A" was in fourth place according to the level of nitrogen oxide emissions, while thermal power plant "Kostolac B" was in fifth place in 2012 and 2013 and in third place in 2014. Spatial distribution of emissions of pollutants is determined according to the level of emissions, in metric tons per annum. Emission values are classified into six levels. Based on the graphic display, it can be concluded that, in the proximity of thermal power plants "Kostolac A" and "Kostolac B", we have the fifth level of emissions of sulfur oxides (from 50,000 to 100,000 $t$ /year) and nitrogen (from 5000 to 10,000 $t$ /year). Based on the spatial distribution of the particulate emissions, it is concluded that thermal power plants "Kostolac

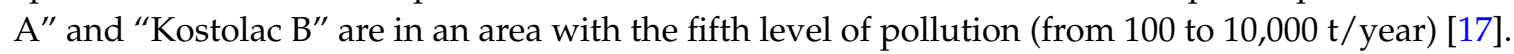

The impact of mining and energy complex on the air quality is assessed on the basis of the reports of accredited laboratories (Mining Institute in Belgrade) and annual reports on the state of air quality in the Republic of Serbia (Environmental Protection Agency). Automatic monitoring of air quality in the Republic of Serbia, under the CARDS Project "Supply of equipment for air quality monitoring stations, Serbia" (EuropeAid/124394/D/SUP/YU), is organized by the Environmental Protection Agency. Operational monitoring of air quality was implemented through the network of automatic stations for monitoring air quality, in accordance with the Decree on establishing the Air Quality Control Program in the state network and in local networks of area monitoring. Automatic monitoring was conducted for measuring the concentration of sulfur dioxide, nitrogen monoxide, nitrogen dioxide, carbon monoxide, and ground-level ozone values [17].

The results of the monitoring of the mass concentration of sulfur dioxide, presented in the Reports on emission tests, measured in flues of TPP "Kostolac A" block 1, boiler 1; TPP "Kostolac A" block 1, boiler 2; TPP "Kostolac A" block 2; TPP "Kostolac B", block 1; and TPP "Kostolac B", block 2, indicate that the recorded values were higher than the prescribed emission limit values. Value for the emission of nitrogen oxides is usually close to the limit values, but occasionally exceeding the prescribed values [18,19].

The average monthly concentrations of soot are higher in spring and winter months, but there are no occurrences of excess average monthly concentration. The values of the total content of sedimentary substances are generally within the prescribed limits, but there are also some that exceed the limit values of total sedimentary substances $\left(450 \mathrm{mg} \cdot \mathrm{m}^{2}\right.$.day), in Drmno (a settlement in the immediate vicinity) emission limit values (ELVs).

\section{Project Management Process for Improving Environmental Protection by Applying a Network Planning Technique}

The management of a mining and energy complex has a duty to promote the environmental protection system and apply necessary legislation [20]. To comply with sustainable development principles, project management should include concrete actions to protect and improve the environment. According to the proposed indicators, the energy development organization is important for reducing harmful consequences and achieving economic benefits [21].

Making of real decisions, based on correct and timely assessment, requires the definition of event probability degree and the analysis of potential effects of coal mining and combustion on environmental quality. Risk is a function of risk event probability $(\mathrm{P})$ and the measure of loss $(\mathrm{L})$ it inflicts:

$$
R=f(P, L)
$$


Actualization of a risk event in a mining and energy complex leads to heavier or smaller economic loss, but also to serious consequences for the environment or loss as non-economic measure [22].

Figure 1 represents the criteria for determination of key problems in the functioning of environmental protection system in a mining and energy complex, in the case of surface mine and thermal power plant "Kostolac" in the Republic of Serbia [23].

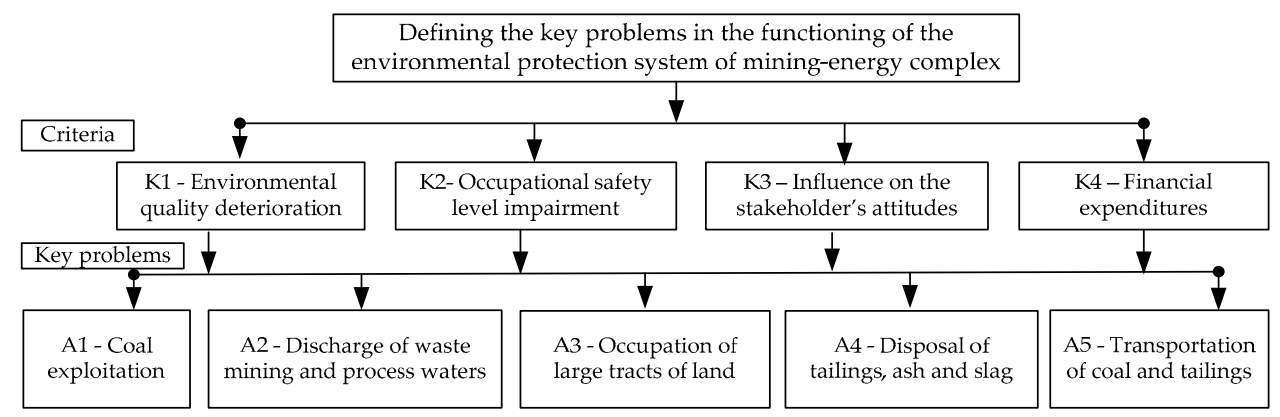

Figure 1. Defining key problems in operation of the environmental protection system in mining and energy complexes.

Aspects of environmental protection in the mining and energy complex were discussed based on the analysis of dominant problems in the functioning of the environmental protection system. A proposal of aspects for key problems (A1, A2, A3, A4, and A5) is given in Table 2.

The significance of the environmental aspects is defined based on the value of the product between the degree of impact scores and the occurrence likelihood of critical consequences of work activities, according to the defined criteria (Figure 1). The degree of impact (S) of the environmental aspect (Table 3 ) is scored with values from 3 to -3 , with score -3 representing an essentially positive impact, while score 3 represents a seriously negative impact. The probability of occurrence of events $(\mathbf{V})$ has a value of 1 to 3 , with the score 1 indicating the emergence of critical activities consequences on an annual basis, score 2 on a monthly basis, and score 3 indicating the continuous presence of the aspect. The values for the degree of impact and probability of occurrence of the events are presented in Table 3 , based on the Report on the State of the Environment [24,25].

Table 2. Selection of environmental aspects.

\begin{tabular}{|c|c|c|}
\hline \multicolumn{3}{|c|}{ Environmental Protection Aspects in Mining and Energy Complex } \\
\hline Key issues & Proposal of environmental aspects & Mark \\
\hline Coal exploitation & $\begin{array}{l}\text { The presence of dust in the pits and slopes } \\
\text { Emissions of exhaust gases and dust during the operation of mining machines }\end{array}$ & A1 \\
\hline $\begin{array}{l}\text { Discharge of waste } \\
\text { mining and process } \\
\text { waters }\end{array}$ & $\begin{array}{c}\text { Unfavorable location of the mine in relation to the catchment area } \\
\text { Irregular treatment of mine waters } \\
\text { Discharge of untreated waste process water }\end{array}$ & A2 \\
\hline $\begin{array}{l}\text { Occupation of large } \\
\text { tracts of land }\end{array}$ & $\begin{array}{l}\text { Increasing the surface area of permanently destroyed area } \\
\text { Increasing the surface area of the buried humus layer } \\
\text { Emissions of heavy metals into the surrounding land }\end{array}$ & A3 \\
\hline $\begin{array}{l}\text { Disposal of tailings, ash } \\
\text { and slag }\end{array}$ & $\begin{array}{l}\text { Improper disposal of tailings } \\
\text { Inadequate disposal of sludge } \\
\text { Irregular sprinkling of ash landfill }\end{array}$ & A4 \\
\hline $\begin{array}{l}\text { Transportation of coal } \\
\text { and tailings }\end{array}$ & $\begin{array}{l}\text { Exhaust gas emissions during the transportation of coal with trucks } \\
\text { Dust emissions during transportation of coal with conveyor belts }\end{array}$ & A5 \\
\hline
\end{tabular}

Analysis of the impact of the mining and energy complex "Kostolac" indicates that there are serious problems. The impact on environmental quality (A1) was given a score of 3 because of the probability of exceeding the limit values and the degree of impact that indicates a significant deterioration in the quality of the environment (score 2). Disposal of wastewater and process water 
(A2); taking up large areas of land (A3); and inadequate disposal of tailings, ash, and slag (A4) have continuous negative impact on the quality of water and soil, with the maximum value for the degree of impact. The impact of transport of coal and tailings on environmental quality is estimated with a second degree of impact and probability of occurrence, as the dust becomes dispersed during adverse weather conditions and wind flows. The probability of occurrence is mostly valued 1 for all aspects if we rank the effects of damaging the health and safety of employees (K2) and the views of interested parties (K3). It is characteristic that the significance of the aspects has the value of 4 when considering the impact on the financial situation in the event of degradation of the working environment quality. The degree of impact should not be ignored, especially when considering coal exploitation (A1).

Based on the value of total significance of the environmental aspects (Table 3), we conclude that the impact on air, water, and land quality of the environment (A1) has a dominant influence, which is evident in the graphical display of the significance of ranked aspects (Figure 2).

Table 3. Determining the significance of environmental aspects based on the level of influence and occurrence probability.

\begin{tabular}{|c|c|c|c|c|c|c|c|c|c|}
\hline \multirow{3}{*}{$\begin{array}{c}\text { Mark of } \\
\text { Environmental } \\
\text { Aspects }\end{array}$} & \multicolumn{8}{|c|}{ Criteria for Assessing the Environmental Aspects } & \multirow{3}{*}{$\begin{array}{c}\text { Total Significance } \\
\text { of Aspects }\end{array}$} \\
\hline & \multicolumn{2}{|c|}{ K1 } & \multicolumn{2}{|c|}{ K2 } & \multicolumn{2}{|c|}{ K3 } & \multicolumn{2}{|c|}{ K4 } & \\
\hline & $S$ & $\mathbf{V}$ & $S$ & $\mathbf{V}$ & $S$ & $\mathbf{V}$ & $S$ & $\mathbf{V}$ & \\
\hline A1 & 2 & 3 & 3 & 3 & 2 & 1 & 3 & 2 & 23 \\
\hline $\mathrm{A} 2$ & 3 & 3 & 2 & 1 & 2 & 2 & 2 & 2 & 19 \\
\hline A3 & 3 & 3 & 1 & 1 & 2 & 1 & 2 & 2 & 16 \\
\hline A4 & 3 & 3 & 1 & 1 & 2 & 1 & 2 & 2 & 16 \\
\hline A5 & 2 & 2 & 1 & 1 & 2 & 1 & 2 & 2 & 11 \\
\hline
\end{tabular}

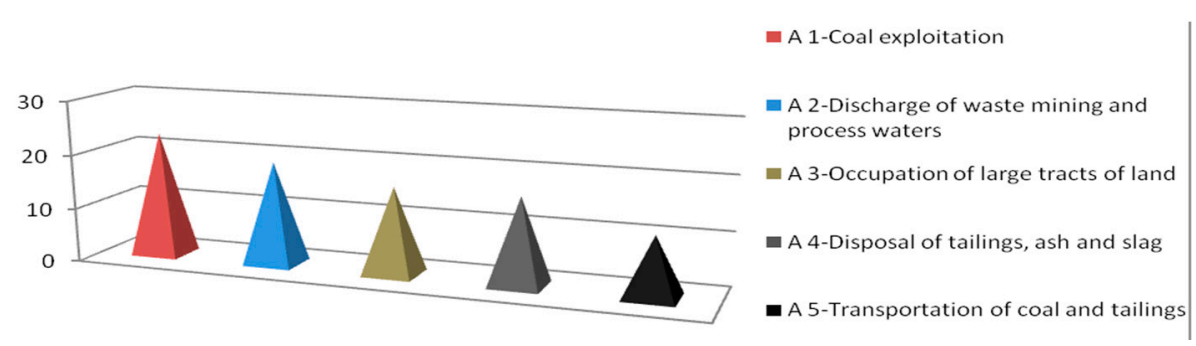

Figure 2. Significance of ranked environmental aspects.

Based on the graphic display of significance of the environmental aspects, we observe the dominance of criteria $\mathrm{K} 2, \mathrm{~K} 1$, and $\mathrm{K} 4$ when ranking the influence of coal exploitation, and the dominance of criteria $\mathrm{K} 1$ when we consider the effects of discharge of waste mining and process water and taking up of large areas of land.

The previous calculus is grounded on risk management approach, which includes: the model of aspect importance evaluation based on aspect seriousness evaluation, probability of occurrence and quantity, as key elements for defining aspect importance [22]. There are five categories of the probability of occurrence of harmful effects from mining and energy complex operational activities. It is graded from 1 to 5 as follows: at least daily (5); at least weekly (4); at least monthly (3); at least annually (2); and less than annually (1). The quantity is graded 0 to 3 , with the following categories: aspect of national importance (3); aspect of organizational importance (2); negligible or accumulates expenditure (1); and negligible and does not accumulate expenditure (0). The product of these two parameters is the impact scale, which is then multiplied by the sum of positive answers to six questions, which are specific to the defined environmental aspects and also relevant for risk assessment. The seriousness of the impact of environmental aspects and risks from the mining and energy complexes on the quality of basic environmental elements is evaluated based on the following questions: 
- Is the aspect regulated by the law and is coal mining and combustion suspended if legal requirements are not adhered to?

- Is the aspect connected to air quality?

- Is the aspect connected to water quality?

- Is the aspect connected to soil quality?

- Is the aspect connected to cross-border pollution?

- Is the aspect connected to direct negative impact on human health?

A positive answer to any of the questions is graded 1 and a negative 0 . Table 4 presents the proposal for defining risk evaluation $(R)$ and determining the importance of proposed environmental aspects $(I)$, according to probability of occurrence, quantity, and seriousness of impact [26].

A comprehensive analysis of ranked environmental aspects is a basis for the ranking of the elements of risk of mining and energy complex operational activities to environmental quality. Implementation of the proposed risk assessment procedures is the basis for the examination of an entire spectrum of risks, from the relatively frequent events with minimal consequences (4 and 7), to low-probability accidents that can considerably degrade environmental quality (19 and 33). The environmental aspects evaluated important for water, soil $(6,23,24,30,31,32$, and 34), and air quality degradation (50) are the key problems to be considered during risk management and on whose basis a risk prevention plan is to be devised. Nevertheless, lower-ranked aspects are also an important part of risk management as they warn about new sources of hazard, even though they are not considered critical activities.

The results of the calculations presented in the table constitute the basis for decision-making, and the objectivity of assessment directly influences the implementation of risk management procedures. Efficiency in risk prevention and establishment of the causes of operational activity risks in mining and energy complexes are the prerequisite for quality organization of preventive measures of environmental protection, for reduction of financial loss due to amelioration of the effects, and for minimization of the time to complete the tasks of the environmental management system. The problem with accomplishing the goals of risk management lies in the structural limitations based on the definition of relationships between financial and technical conditions for the use of required safety measures and acceptance of responsibility for the occurrence of a risk event. Risk management based on the balance between meeting required legal and ethical criteria on one hand and financial and technical limitations on the other hand requires a model of the management process and the establishment of the time needed for completion of the necessary activities. Operative plan of risk assessment should be defined so as to minimize the maximum time needed for its completion and thus avoid postponing problem resolution, which would increase the probability of a risk event, which is a frequent occurrence in mining and energy complexes. 
Table 4. Determination of environmental aspect importance (I) based on probability of occurrence (PO), quantity (Q), and impact seriousness (IS).

\begin{tabular}{|c|c|c|c|c|c|}
\hline \multirow{2}{*}{ Title } & \multirow{2}{*}{ Environmental Protection Aspects of Mining and Energy Complexes as Risk Assessment Elements } & \multicolumn{3}{|c|}{ Criteria for Environmental Aspect Evaluation } & \multirow{2}{*}{$R(I)$} \\
\hline & & $P O$ & $Q$ & IS & \\
\hline 1 & Presence of dust on mining slopes & 5 & 2 & $1+1+1+1+0+1$ & 50 \\
\hline 2 & Exhaust and dust emission during the operation of mining machinery & 5 & 2 & $1+1+0+1+0+1$ & 40 \\
\hline 3 & Dust dispersal into the surrounding soil & 5 & 2 & $1+0+0+1+0+1$ & 30 \\
\hline 4 & Unfavorable location of the mine in relation to the catchment area & 5 & 1 & $1+0+1+0+0+1$ & 15 \\
\hline 5 & Larger permanently destroyed area & 2 & 3 & $1+1+1+1+1+1$ & 36 \\
\hline 6 & Irregular treatment of mine waters & 5 & 3 & $1+0+1+1+0+1$ & 60 \\
\hline 7 & Improper tailings disposal & 5 & 1 & $1+1+1+1+0+1$ & 25 \\
\hline 8 & Dust emission during tailings disposal & 4 & 2 & $1+1+0+1+0+0$ & 24 \\
\hline 9 & Larger area of covered humus layer & 5 & 3 & $0+0+0+1+0+0$ & 15 \\
\hline 10 & Tailings pond area rinsing & 3 & 2 & $0+0+1+1+0+1$ & 18 \\
\hline 11 & Irregular treatment of tailings pond leachate & 3 & 2 & $0+0+1+1+0+1$ & 18 \\
\hline 12 & Presence of dust and coal at loading sites & 5 & 2 & $1+1+0+1+0+1$ & 40 \\
\hline 13 & Irregular dust settling at transfer points & 5 & 2 & $1+1+0+1+0+1$ & 40 \\
\hline 14 & Exhaust and dust emission during loading and unloading of coal & 5 & 2 & $1+1+0+1+0+1$ & 40 \\
\hline 15 & Exhaust emission during coal transport by trucks & 5 & 2 & $1+1+0+1+0+1$ & 40 \\
\hline 16 & Dust emission during coal transport by conveyor belts & 4 & 2 & $1+1+0+1+0+0$ & 24 \\
\hline 17 & Atmospheric precipitation runoff from roads into groundwater courses & 3 & 3 & $1+0+1+0+0+1$ & 27 \\
\hline 18 & Oil runoff by atmospheric precipitation from roads and loading/unloading sites & 3 & 3 & $1+0+1+0+0+1$ & 27 \\
\hline 19 & Road sprinkling and polluted water runoff into groundwater courses & 1 & 2 & $0+0+0+0+0+1$ & 3 \\
\hline 20 & Atmospheric precipitation runoff from roads into surrounding soil & 3 & 2 & $1+0+0+1+0+1$ & 18 \\
\hline 21 & Incomplete coal combustion & 1 & 3 & $1+1+0+0+1+1$ & 12 \\
\hline 22 & Irregular replacement of air purification filters & 1 & 3 & $1+1+0+0+1+1$ & 12 \\
\hline 23 & Exceeded air pollutant emission and immission limit values & 5 & 3 & $1+1+0+0+1+1$ & 60 \\
\hline 24 & Release of untreated process wastewater & 5 & 3 & $1+0+1+0+1+1$ & 60 \\
\hline 25 & Release of process water used for slag slaking and cooling & 5 & 3 & $1+0+1+0+0+1$ & 45 \\
\hline 26 & Improper sludge disposal & 3 & 3 & $1+0+1+1+0+1$ & 36 \\
\hline 27 & Ash dispersal into surrounding surface water due to wind & 4 & 2 & $1+0+1+0+0+0$ & 16 \\
\hline 28 & Ash-hole rinsing by atmospheric precipitation & 3 & 3 & $1+0+1+1+0+1$ & 36 \\
\hline 29 & Irregular ash dump sprinkling & 4 & 3 & $0+1+0+1+0+1$ & 36 \\
\hline 30 & Unfavorable ash and water ratio in the thick pulp & 5 & 3 & $1+0+1+0+0+1$ & 60 \\
\hline 31 & Increased concentration of heavy metals in overflowing, drainage, and leachate water & 5 & 3 & $1+0+1+1+0+1$ & 60 \\
\hline 32 & Increased acidity of overflowing, drainage, and leachate water & 5 & 3 & $1+0+1+1+0+1$ & 60 \\
\hline 33 & Dam failure and flowing of water and ash into the recipient & 1 & 3 & $1+0+1+1+1+1$ & 15 \\
\hline 34 & Heavy metal emission into the surrounding soil & 5 & 3 & $1+0+1+1+0+1$ & 60 \\
\hline 35 & Emission of solid particles and gases during spontaneous combustion of coal & 2 & 3 & $1+1+0+0+1+1$ & 24 \\
\hline
\end{tabular}


Network Planning Technique-Critical Path Method (CPM)

A network planning technique is a good starting point for project management, definition of activities, and representation of the logical structure. Application of the Critical Path Method (CPM) and precisely defined activity durations allow the creation of project management models with adjustments to the mining and energy complex environmental protection systems in accordance with the sustainable development principles [27].

The first phase of the project management system for improving environmental protection in energy complexes is the definition of the necessary model actions which would adhere to the basic principles of sustainable development. Table 5 presents project activities. The relation between activities and their order of execution has been established within the defined project management activities (Table 5). The defined activities form the basis for the realization of management program by applying the MS Project software package. Figure 3 gives an order of execution of the project activities to improve the environmental protection system in mining and energy complexes.

Table 5. A list of project management activities with the defined duration and schedule of activities.

\begin{tabular}{|c|c|c|c|}
\hline No. & Project Management Activities & Time $(t)$ & Mark $(i-j)$ \\
\hline 1 & $\begin{array}{l}\text { Defining real possibilities for improving the environmental protection } \\
\text { system in mining and energy complexes }\end{array}$ & 2 & $1-2$ \\
\hline 2 & $\begin{array}{l}\text { Selecting multidisciplinary team members for the correction of the } \\
\text { environmental protection system }\end{array}$ & 1 & $2-3$ \\
\hline 3 & $\begin{array}{l}\text { Defining key problems in the functioning of mining and energy complex } \\
\text { protection systems }\end{array}$ & 1 & $3-4$ \\
\hline 4 & $\begin{array}{l}\text { Defining the impact of energy complex operations on } \\
\text { environmental quality }\end{array}$ & 1 & $2-5$ \\
\hline 5 & $\begin{array}{l}\text { Analyzing the possibility of applying the basic principles of sustainable } \\
\text { development in the energy sector }\end{array}$ & 2 & $4-5$ \\
\hline 6 & $\begin{array}{l}\text { Selecting the basic sustainable development principles on which } \\
\text { management system improvement would be based }\end{array}$ & 1 & $5-6$ \\
\hline 7 & Investigating air quality effects of coal dust & 2 & $6-7$ \\
\hline 8 & Investigating air quality effects of emitted ash and gaseous products & 2 & $7-13$ \\
\hline 9 & $\begin{array}{l}\text { Establishing ratios for concentrations of particulate matter and sulfur } \\
\text { dioxide in the air and their acceptable values }\end{array}$ & 1 & $13-20$ \\
\hline 10 & $\begin{array}{l}\text { Investigating the effects of untreated mine wastewater, landfill leachate, } \\
\text { and ash }\end{array}$ & 3 & $6-8$ \\
\hline 11 & $\begin{array}{l}\text { Establishing ratios for concentrations of heavy metals in wastewater and } \\
\text { their acceptable values }\end{array}$ & 1 & $8-20$ \\
\hline 12 & $\begin{array}{l}\text { Investigating the effects of surface exploitation on the humus layer } \\
\text { destruction of abandoned areas and on the quality of agricultural land }\end{array}$ & 1 & $6-9$ \\
\hline 13 & $\begin{array}{l}\text { Investigating the effects of ash disposal on the humus layer destruction of } \\
\text { abandoned areas and on the quality of agricultural land }\end{array}$ & 1 & 9-14 \\
\hline 14 & $\begin{array}{l}\text { Establishing ratios for concentrations of heavy metals in soil and their } \\
\text { acceptable values }\end{array}$ & 1 & $14-20$ \\
\hline 15 & $\begin{array}{l}\text { Identifying vulnerabilities in the application of applicable laws in the } \\
\text { field of environmental protection }\end{array}$ & 1 & $6-10$ \\
\hline 16 & Identifying vulnerabilities in the application of EU directives & 1 & $10-15$ \\
\hline 17 & Considering opportunities for active environmental protection & 1 & $15-21$ \\
\hline 18 & Identifying gaps in the preventive safety measures & 4 & $16-16$ \\
\hline 19 & Considering financial and technical causes of threats to the environment & 1 & $16-21$ \\
\hline 20 & Identifying causes of the adverse effects caused by operations & 1 & $6-11$ \\
\hline 21 & $\begin{array}{l}\text { Identifying opportunities for eliminating causes of the adverse effects } \\
\text { caused by operations }\end{array}$ & 2 & $11-17$ \\
\hline
\end{tabular}


Table 5. Cont.

\begin{tabular}{|c|c|c|c|}
\hline No. & Project Management Activities & Time $(t)$ & Mark $(i-j)$ \\
\hline 22 & $\begin{array}{c}\text { Considering the need for environmental education and ethical attitude } \\
\text { change in the management }\end{array}$ & 1 & $17-21$ \\
\hline 23 & Analyzing studies on the country's energy potential & 2 & $6-12$ \\
\hline 24 & Considering coal reserves & 2 & $12-18$ \\
\hline 25 & $\begin{array}{l}\text { Identifying opportunities for rational consumption of coal, promoting } \\
\text { energy efficiency, and reducing energy losses }\end{array}$ & 1 & $18-22$ \\
\hline 26 & Analyzing the annual level of coal exploitation & 3 & $6-19$ \\
\hline 27 & $\begin{array}{c}\text { Data analyzing on GDP per unit of consumption and total emissions of } \\
\text { carbon dioxide per GDP unit }\end{array}$ & 1 & $19-22$ \\
\hline 28 & $\begin{array}{l}\text { Analyzing and evaluating harmful consequences of coal exploitation and } \\
\text { coal combustion }\end{array}$ & 1 & $20-23$ \\
\hline 29 & $\begin{array}{l}\text { Creating amendment proposals on the adopted short- and long-term } \\
\text { goals of environmental protection }\end{array}$ & 3 & $21-26$ \\
\hline 30 & $\begin{array}{l}\text { Identifying opportunities for rationalization of coal consumption as a } \\
\text { natural resource }\end{array}$ & 1 & $22-25$ \\
\hline 31 & Predicting risks to human health and the state of the environment & 2 & $23-26$ \\
\hline 32 & Creating amendment proposals on the adopted environmental policy & 1 & $24-26$ \\
\hline 33 & $\begin{array}{l}\text { Analyzing energy consumption and possibilities for changing } \\
\text { the modalities }\end{array}$ & 1 & $25-26$ \\
\hline 34 & $\begin{array}{c}\begin{array}{c}\text { Establishing procedures to stop neglecting the importance of } \\
\text { environmental degradation }\end{array}\end{array}$ & 2 & $26-27$ \\
\hline 35 & $\begin{array}{l}\text { Establishing procedures for work activities with reduced environmental } \\
\text { pollution and compliance with European standards }\end{array}$ & 6 & $27-28$ \\
\hline 36 & $\begin{array}{l}\text { Preparing the documentation for the implementation of regular analysis } \\
\text { procedures on the impact of work activities and timely risk identification }\end{array}$ & 1 & $28-29$ \\
\hline 37 & $\begin{array}{l}\text { Proposing the implementation of basic sustainable development } \\
\text { principles in the process of improving the EMS }\end{array}$ & 2 & $29-30$ \\
\hline
\end{tabular}

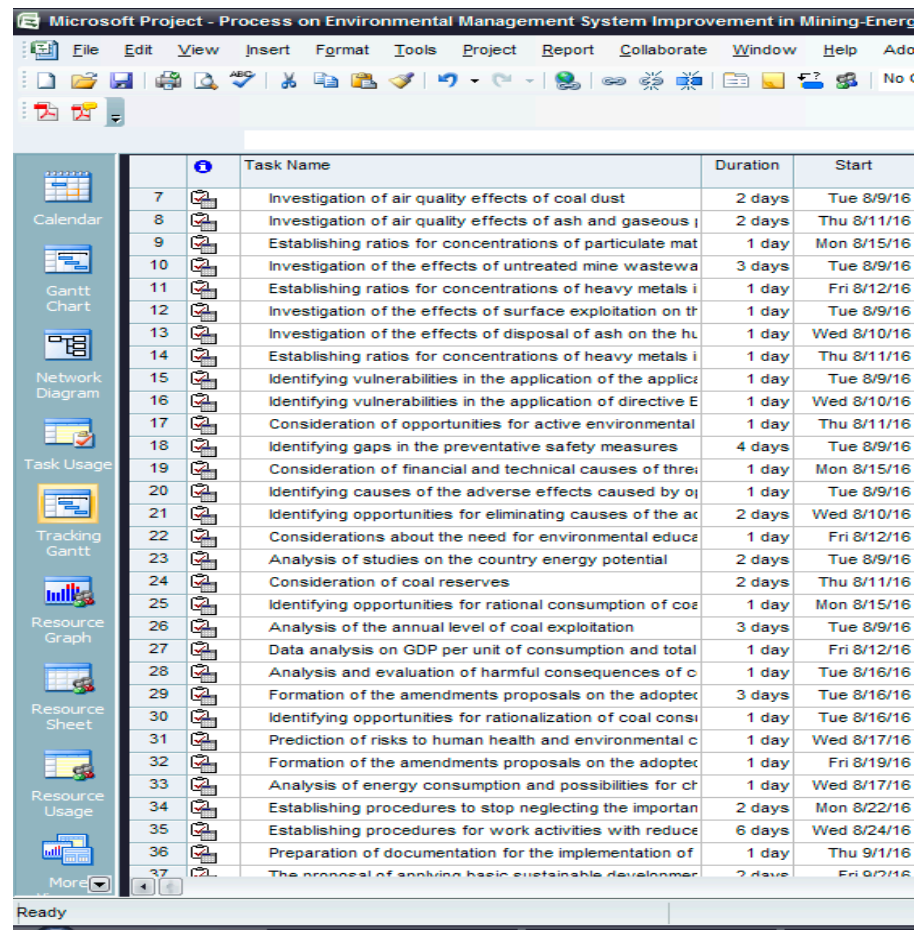

Figure 3. Time duration and order of execution of the project activities to improve environmental protection system in mining and energy complexes. 
The key activity of the project to improve the environmental protection system in mining and energy complexes is to determine the procedures to terminate the neglect of values of environmental degradation $\left(\mathrm{n}_{34}\right)$, which takes place after the prediction of risks to human health and the environment $\left(n_{34}\right)$, formation of the proposals for amendments of the adopted environmental protection policy $\left(n_{34}\right)$, and analysis of energy consumption and opportunities for changing the means $\left(\mathrm{n}_{34}\right)$, which is evident from Figure 4.

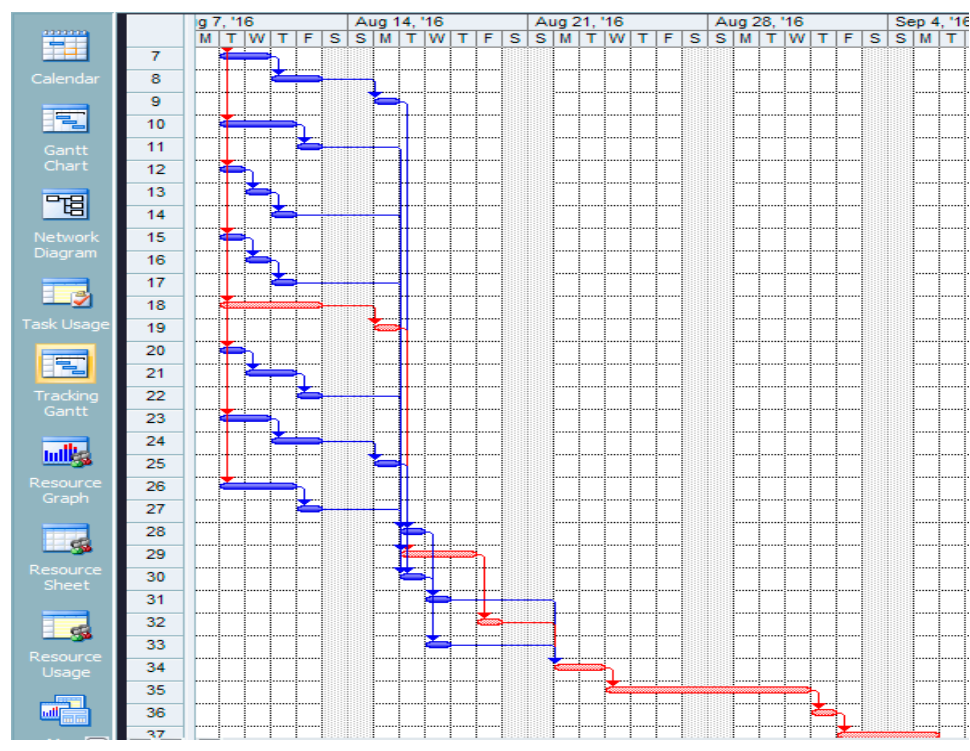

Figure 4. Illustrative part of gantographic display of the project to improve the environmental protection system in mining and energy complexes.

Time analysis per CPM begins with the evaluation of time for each activity $\left(t_{i j}\right)$, on the basis of which we calculate the earliest and latest time of event occurrence. The earliest time for event occurrence $\left(T_{E}\right)$ is the sum of the earliest occurrence of the event and the duration of the activity $t_{i j}[8]$ :

$$
(T E) j=\max _{i \in x_{i}}\left\{\left(T_{E}\right) i-t_{i j}\right\} ;(T E) 0=0
$$

where $x_{j}$ denotes the set of all the events from which it can move directly into the event $j$ only through one activity $(i, j)$.

Time scheduled for harmonization of the environmental management system with the principles of sustainable development is equated with the latest time for event occurrence [8]:

$$
\left(T_{L}\right)_{n}=\left(T_{E}\right)_{n}
$$

The latest time for event occurrence $\left(T_{L}\right)$ is represented by the formula:

$$
(P L) i=\min _{j \in y_{i}}\left\{(T L) i-t_{i j}\right\}
$$

where $y_{i}$ denotes the set of events that can be directly crossed into from the event and only through one activity $(i, j)[8]$.

The total, free, and independent time reserves are determined according to activity duration, by means of the following expressions [8]:

$$
\begin{aligned}
& P i j=(T L) j-(T E) i-t_{i j} \\
& S i j=(T E) j-(T E) i-t_{i j}
\end{aligned}
$$




$$
N i j=\max \left\{0,(T E) j-(T L) i-t_{i j}\right\}
$$

Based on the defined duration times for the activities, we analyzed the duration of activities, represented by Equations (2) and (7). Table 6 presents the results of event occurrence analysis.

Table 6. Results of activity duration analysis within project management.

\begin{tabular}{|c|c|c|c|c|c|c|c|c|c|}
\hline \multirow{3}{*}{$\begin{array}{c}\text { No. } \\
n \\
\end{array}$} & \multirow{3}{*}{$\begin{array}{c}\text { Mark } \\
(i-j)\end{array}$} & \multirow{3}{*}{$\begin{array}{l}\text { Time } \\
\left(t_{i j}\right)\end{array}$} & \multirow{2}{*}{\multicolumn{2}{|c|}{ Event Duration $i$}} & \multirow{2}{*}{\multicolumn{2}{|c|}{ Event Duration $j$}} & \multicolumn{3}{|c|}{ Time Reserves } \\
\hline & & & & & & & \multirow{2}{*}{$\begin{array}{c}\text { Total } \\
P_{i j} \\
\end{array}$} & \multirow{2}{*}{$\begin{array}{c}\text { Free } \\
S_{i j} \\
\end{array}$} & \multirow{2}{*}{$\begin{array}{c}\text { Independent } \\
N_{i j}\end{array}$} \\
\hline & & & $\left(T_{E}\right)_{i}$ & $\left(T_{L}\right)_{i}$ & $\left(T_{E}\right)_{j}$ & $\left(T_{L}\right)_{j}$ & & & \\
\hline $1 *$ & $1-2$ & 2 & 0 & 0 & 2 & 2 & 0 & 0 & 0 \\
\hline $2 *$ & $2-3$ & 1 & 2 & 2 & 3 & 3 & 0 & 0 & 0 \\
\hline $3 *$ & $3-4$ & 1 & 3 & 3 & 4 & 4 & 0 & 0 & 0 \\
\hline $4 *$ & $2-5$ & 1 & 4 & 4 & 5 & 5 & 0 & 0 & 0 \\
\hline 5 & $4-5$ & 2 & 2 & 2 & 5 & 5 & 1 & 1 & 1 \\
\hline $6 *$ & $5-6$ & 1 & 5 & 5 & 6 & 6 & 0 & 0 & 0 \\
\hline 7 & $6-7$ & 2 & 6 & 6 & 8 & 9 & 1 & 0 & 0 \\
\hline 8 & $7-13$ & 2 & 8 & 9 & 10 & 11 & 1 & 0 & 0 \\
\hline 9 & $13-20$ & 1 & 10 & 11 & 11 & 12 & 1 & 0 & 0 \\
\hline 10 & $6-8$ & 3 & 6 & 6 & 9 & 11 & 2 & 0 & 0 \\
\hline 11 & $8-20$ & 1 & 9 & 11 & 11 & 12 & 2 & 1 & 0 \\
\hline 12 & $6-9$ & 1 & 6 & 6 & 7 & 10 & 3 & 0 & 0 \\
\hline 13 & $9-14$ & 1 & 7 & 10 & 8 & 11 & 3 & 0 & 0 \\
\hline 14 & $14-20$ & 1 & 8 & 11 & 11 & 12 & 3 & 2 & 0 \\
\hline 15 & $6-10$ & 1 & 6 & 6 & 7 & 9 & 2 & 0 & 0 \\
\hline 16 & 10-15 & 1 & 7 & 9 & 8 & 10 & 2 & 0 & 0 \\
\hline 17 & $15-21$ & 1 & 8 & 10 & 11 & 11 & 2 & 2 & 0 \\
\hline $18 *$ & $16-16$ & 4 & 6 & 6 & 10 & 10 & 0 & 0 & 0 \\
\hline $19 *$ & $16-21$ & 1 & 10 & 10 & 11 & 11 & 0 & 0 & 0 \\
\hline 20 & 6-11 & 1 & 6 & 6 & 7 & 8 & 1 & 0 & 0 \\
\hline 21 & $11-17$ & 2 & 7 & 8 & 9 & 10 & 1 & 0 & 0 \\
\hline 22 & $17-21$ & 1 & 9 & 10 & 11 & 11 & 1 & 1 & 0 \\
\hline 23 & 6-12 & 2 & 6 & 6 & 8 & 10 & 2 & 0 & 0 \\
\hline 24 & $12-18$ & 2 & 8 & 10 & 10 & 12 & 2 & 0 & 0 \\
\hline 25 & $18-22$ & 1 & 10 & 12 & 11 & 13 & 2 & 0 & 0 \\
\hline 26 & 6-19 & 3 & 6 & 6 & 9 & 12 & 3 & 0 & 0 \\
\hline 27 & $19-22$ & 1 & 9 & 12 & 11 & 13 & 3 & 1 & 0 \\
\hline 28 & $20-23$ & 1 & 11 & 12 & 12 & 13 & 1 & 0 & 0 \\
\hline 29 * & $21-26$ & 3 & 11 & 11 & 14 & 14 & 0 & 0 & 0 \\
\hline 30 & $22-25$ & 1 & 11 & 13 & 12 & 14 & 2 & 0 & 0 \\
\hline 31 & $23-26$ & 2 & 12 & 13 & 15 & 15 & 1 & 1 & 0 \\
\hline 32 * & $24-26$ & 1 & 14 & 14 & 15 & 15 & 0 & 0 & 0 \\
\hline 33 & $25-26$ & 1 & 12 & 14 & 15 & 15 & 2 & 2 & 0 \\
\hline 34 * & $26-27$ & 2 & 15 & 15 & 17 & 17 & 0 & 0 & 0 \\
\hline $35 *$ & $27-28$ & 6 & 17 & 17 & 23 & 23 & 0 & 0 & 0 \\
\hline $36^{*}$ & $28-29$ & 1 & 23 & 23 & 24 & 24 & 0 & 0 & 0 \\
\hline $37 *$ & $29-30$ & 2 & 24 & 24 & 26 & 26 & 0 & 0 & 0 \\
\hline
\end{tabular}

Based on the analysis of activity duration (Tables 5 and 6), we determined the critical path (Figure 4). It represents a chain of interrelated activities that have the same earliest and latest time durations. It stretches between the initial and the final event.

Based on the network plan (Figure 4), we conclude that special attention should be given to the activities that belong to the critical path. It is necessary to extend the time for consideration of basic principles of sustainable development on which to base the improvement of the management system $\left(\mathrm{n}_{6}\right)$, but also for the activities $\mathrm{n}_{1}, \mathrm{n}_{2}, \mathrm{n}_{3}, \mathrm{n}_{4}, \mathrm{n}_{5}, \mathrm{n}_{6}, \mathrm{n}_{18}, \mathrm{n}_{19}, \mathrm{n}_{29}, \mathrm{n}_{32}, \mathrm{n}_{34}, \mathrm{n}_{35}, \mathrm{n}_{36}$ and $\mathrm{n}_{37}$, as can be seen in Table 6. The process of making a model for project management starts with critical activities related to the consideration of options for improving the management system $\left(\mathrm{n}_{1}\right)$, selection of members of the multidisciplinary team $\left(\mathrm{n}_{2}\right)$, and analysis of the basic principles of sustainable development $\left(\mathrm{n}_{3}\right)$, which is evident in the initial part of the gantographic display (Figure 5) and the network plan (Figure 6). 


\begin{tabular}{|c|c|c|c|c|c|c|c|c|c|c|c|c|c|c|c|c|}
\hline & (1) & Duration & Start & Finish & Predecessors & Successors $F$ & F 31, & 16 & & & & & $\mathrm{Au}$ & ig 7 & "16 & \\
\hline & & & & & & & & $1 / \mathrm{w}$ & & 1 & $F$ & 51 & s & $\mathrm{M}$ & $T$ & w \\
\hline 1 & 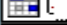 & 2 days & Mon 8/1/16 & Tue $8 / 2 / 16$ & & 2 & & 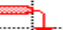 & & & & & & & & \\
\hline 2 & 驺 & 1 day & Wed $8 / 3 / 16$ & Wed $8 / 3 / 16$ & 1 & 3,5 & & & & & & & & & & \\
\hline 3 & 唈 & 1 day & Thu $8 / 4 / 16$ & Thu $8 / 4 / 16$ & 2 & 4 & & & & & & & & & & \\
\hline 4 & 勻 & 1 day & Fri 8/5/16 & Fri $8 / 5 / 16$ & 3 & 6 & & & & & & & & & & \\
\hline 5 & 믐 & 2 days & Thu $8 / 4 / 16$ & Fri $8 / 5 / 16$ & 2 & 6 & & & & 5 & & & & & & \\
\hline 6 & 包 & 1 day & Mon $8 / 8 / 16$ & Mon $8 / 8 / 16$ & 5,4 & $18,20,23,26$ & & & & & & & & & a & \\
\hline
\end{tabular}

Figure 5. Illustrative part of gantographic display of the initial phase of the project to improve the environmental protection system in mining and energy complexes.

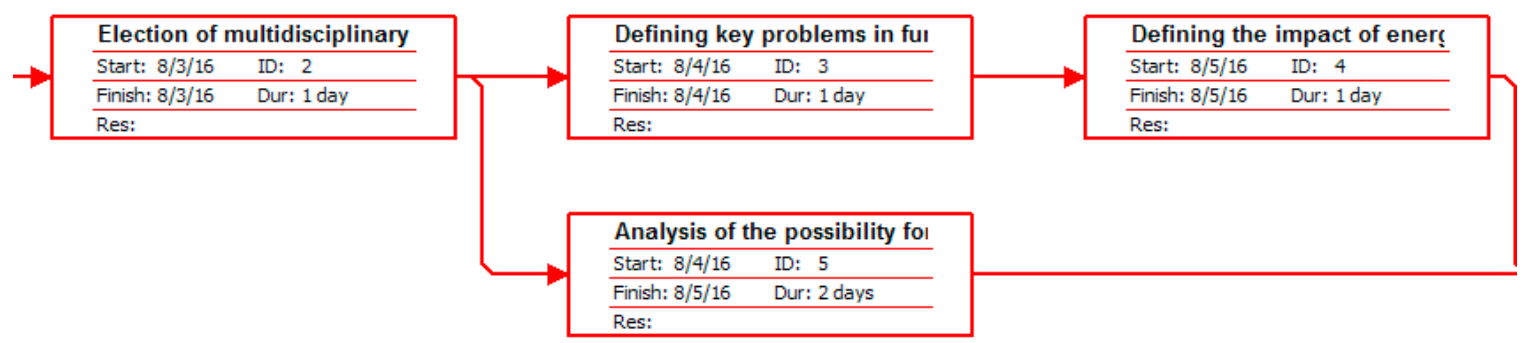

Figure 6. Illustrative part of network diagram of the initial phase of the project to improve the environmental protection system in mining and energy complexes.

The achievement of the initial activities will create conditions for: consequence analysis of mining and energy complex operation $\left(\mathrm{n}_{28}\right)$ on air $\left(\mathrm{n}_{7}, \mathrm{n}_{8}\right.$, and $\left.\mathrm{n}_{9}\right)$, water $\left(\mathrm{n}_{10}\right.$ and $\left.\mathrm{n}_{11}\right)$, and soil $\left(\mathrm{n}_{12}, \mathrm{n}_{13}\right.$, and $\left.\mathrm{n}_{14}\right)$ quality; the determination of failures in environmental protection organization $\left(\mathrm{n}_{15}\right.$ and $\left.\mathrm{n}_{16}\right)$; consideration of the relationship of available energy resources $\left(\mathrm{n}_{23}\right)$; and the level of annual coal exploitation $\left(\mathrm{n}_{24}\right)$, as shown in Figure 7.

\begin{tabular}{|c|c|c|c|c|c|c|c|c|c|}
\hline 5 & & a & Duration & Start & Finish & Predecessors & Successors $F$ & 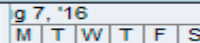 & 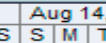 \\
\hline 且 & 7 & 四 & 2 days & Tue 8/9/16 & Wed $8 / 10 / 16$ & 6 & 8 & & \\
\hline Calendar & 8 & 2 & 2 days & Thu $8 / 11 / 16$ & Fri $8 / 12 / 16$ & 7 & 9 & & \\
\hline & 9 & 믄 & 1 day & Mon $8 / 15 / 16$ & Mon $8 / 15 / 16$ & 8 & 28 & & \\
\hline$\Rightarrow$ & 10 & 牙 & 3 days & Tue $8 / 9 / 16$ & Thu $8 / 11 / 16$ & 6 & 11 & & \\
\hline Gantt & 11 & 包 & 1 day & Fri $8 / 12 / 16$ & Fri $8 / 12 / 16$ & 10 & 28 & & \\
\hline Chart & 12 & 늘 & 1 day & Tue $8 / 9 / 16$ & Tue $8 / 9 / 16$ & 6 & 13 & & \\
\hline 坼品 & 13 & 驺 & 1 day & Wed $8 / 10 / 16$ & Wed $8 / 10 / 16$ & 12 & 14 & & \\
\hline & 14 & 늘 & 1 day & Thu $8 / 11 / 16$ & Thu $8 / 11 / 16$ & 13 & 28 & & \\
\hline Network & 15 & 勾 & 1 day & Tue $8 / 9 / 16$ & Tue 8/9/16 & 6 & 16 & & \\
\hline Diagram & 16 & 诮 & 1 day & Wed $8 / 10 / 16$ & Wed $8 / 10 / 16$ & 15 & 17 & & \\
\hline & 17 & 急 & 1 day & Thu $8 / 11 / 16$ & Thu $8 / 11 / 16$ & 16 & 29 & & \\
\hline - & 18 & 筜 & 4 days & Tue 8/9/16 & Fri 8/12/16 & 6 & 19 & & \\
\hline Task Usage & 19 & 匀 & 1 day & Mon $8 / 15 / 16$ & Mon 8/15/16 & 18 & 29 & & \\
\hline & 20 & 匀 & 1 day & Tue $8 / 9 / 16$ & Tue $8 / 9 / 16$ & 6 & 21 & & \\
\hline = & 21 & 匀 & 2 days & Wed $8 / 10 / 16$ & Thu $8 / 11 / 16$ & 20 & 22 & & \\
\hline Tracking & 22 & 驺 & 1 day & Fri $8 / 12 / 16$ & Fri $8 / 12 / 16$ & 21 & 29 & & \\
\hline & 23 & 驺 & 2 days & Tue 8/9/16 & Wed $8 / 10 / 16$ & 6 & 24 & & \\
\hline & 24 & 匀 & 2 days & Thu $8 / 11 / 16$ & Fri $8 / 12 / 16$ & 23 & 25 & & \\
\hline 1 IIII) & 25 & 를 & 1 day & Mon $8 / 15 / 16$ & Mon $8 / 15 / 16$ & 24 & 30 & & \\
\hline
\end{tabular}

Figure 7. Illustrative part of gantographic display of branched structure of the project to improve the environmental protection system in mining and energy complexes.

Branched structure of the management project (Figure 7) points to the importance of activities $n_{28}$, $\mathrm{n}_{29}$, and $\mathrm{n}_{30}$ but also to the need to consider the flaws in applying preventive protection measures $\left(\mathrm{n}_{18}\right)$ and financial-technical reasons of threats to the environment $\left(\mathrm{n}_{19}\right)$, because they belong to the critical activities (Figure 8). Making proposals for changes in the adopted short-term and long-term objectives of environmental protection $\left(\mathrm{n}_{29}\right)$ (prediction of risk), changes to the adopted environmental policy $\left(n_{32}\right)$, and changes in consumption patterns are basic conditions for the application of sustainable development principles in the process of improving the environmental protection management system. 


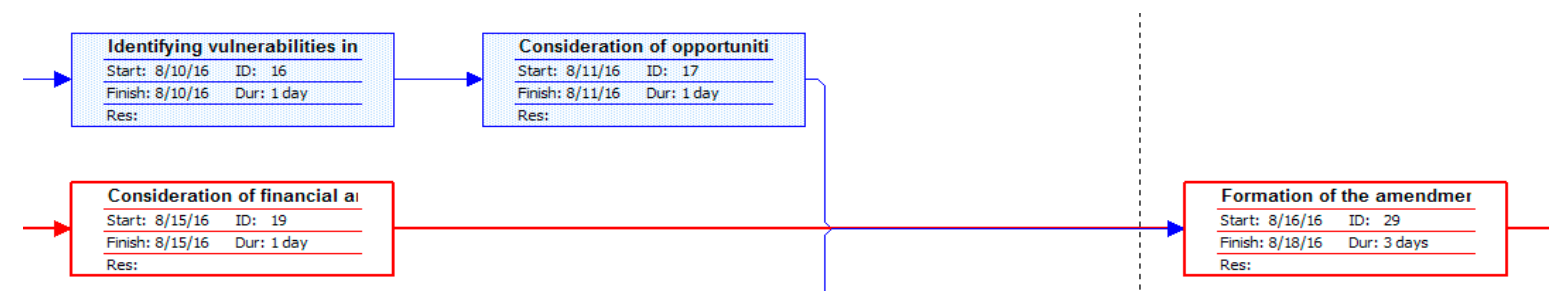

Figure 8. Illustrative part of the network plan of the branched project structure to improve the environmental protection system in mining and energy complexes.

The final phase of the management project, based on establishing procedures for terminating the neglect of values of environmental degradation $\left(\mathrm{n}_{34}\right)$, takes place after the analysis and evaluation of harmful consequences of coal exploitation and combustion $\left(\mathrm{n}_{28}\right)$, making proposals for changes in the adopted short-term and long-term objectives of environmental protection $\left(\mathrm{n}_{29}\right)$, and determination of the abilities to rationalize the consumption of coal as a natural resource $\left(\mathrm{n}_{30}\right)$, as shown in Figure 9.

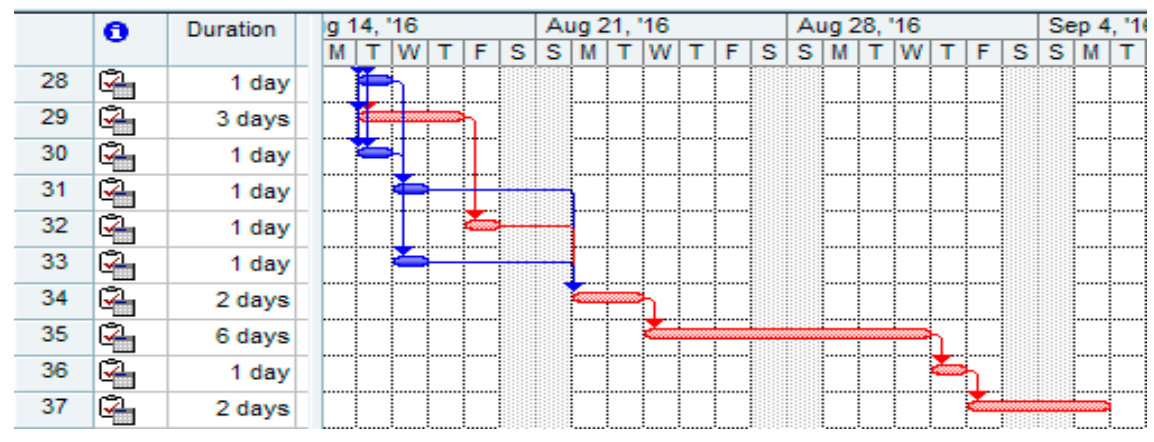

Figure 9. Illustrative part of gantographic display of the initial phase of the project to improve the environmental protection system in mining and energy complexes.

Based on Figure 9, we concluded that attention should be given to the activities $n_{29}, n_{32}, n_{34}, n_{35}$, $\mathrm{n}_{36}$, and $\mathrm{n}_{37}$, as any extension of their duration can lead to delays in project completion. Network plan of final activities (Figure 9 ) shows the activities of the environmental values analysis $\left(\mathrm{n}_{34}\right)$, establishing the procedures of performing work activities while reducing environmental pollution and complying with the European standards $\left(n_{35}\right)$, production of documentation for the implementation of regular analysis procedures for the impact of work activities and timely risk identification $\left(\mathrm{n}_{36}\right)$, and the proposed application of basic principles of sustainable development in the process of improving the environmental management system $\left(\mathrm{n}_{37}\right)$, which take place after the changes in short-term and long-term objectives $\left(\mathrm{n}_{29}\right)$ and changes in the environmental policy $\left(\mathrm{n}_{32}\right)$.

The accomplishment of those activities (Figure 10) is the basis for improving the environmental protection system in mining and energy complex by applying the sustainable development principles, while maintaining energy stability and environmental quality [28]. Not least, improvement of the environmental protection system in mining and energy complex is of particular importance due to the impacts of climate change, which impose new challenges to the mining and energy sector [29]. It is encouraging that the usage of similar approach is evident in contemporary literature, ranging from the field of water and air quality management, to the waste management [30].

Development of mining and energy complex risk management, based on the implementation of the standard ISO 31000:2009, would allow the establishment of internationally acceptable principles, which are also based on quality management guidelines (PDCA (Plan, Do, Check, Act)) [31]. Application of risk management procedures based on the implementation of the standard ISO 31000 for risk assessment in mining and energy complexes is suitable because it encompasses all types of risk (biological, chemical, and physical-according to the degree of identification; accidental or 
cumulative-according to the dynamics of development; risks in planning or operative management stages; risks that are manageable; and risks beyond the control of the management process) [31,32]. Risk management of a mining and energy complex should be based on the organized process of risk identification and evaluation, selection and implementation of operations for risk treatment and monitoring, when the goal is to mind the realization of decision-making aspects in the environmental protection system [33]. Mining and energy complexes are enterprises with considerable environmental risks, i.e., risks that could significantly degrade environmental quality [34].

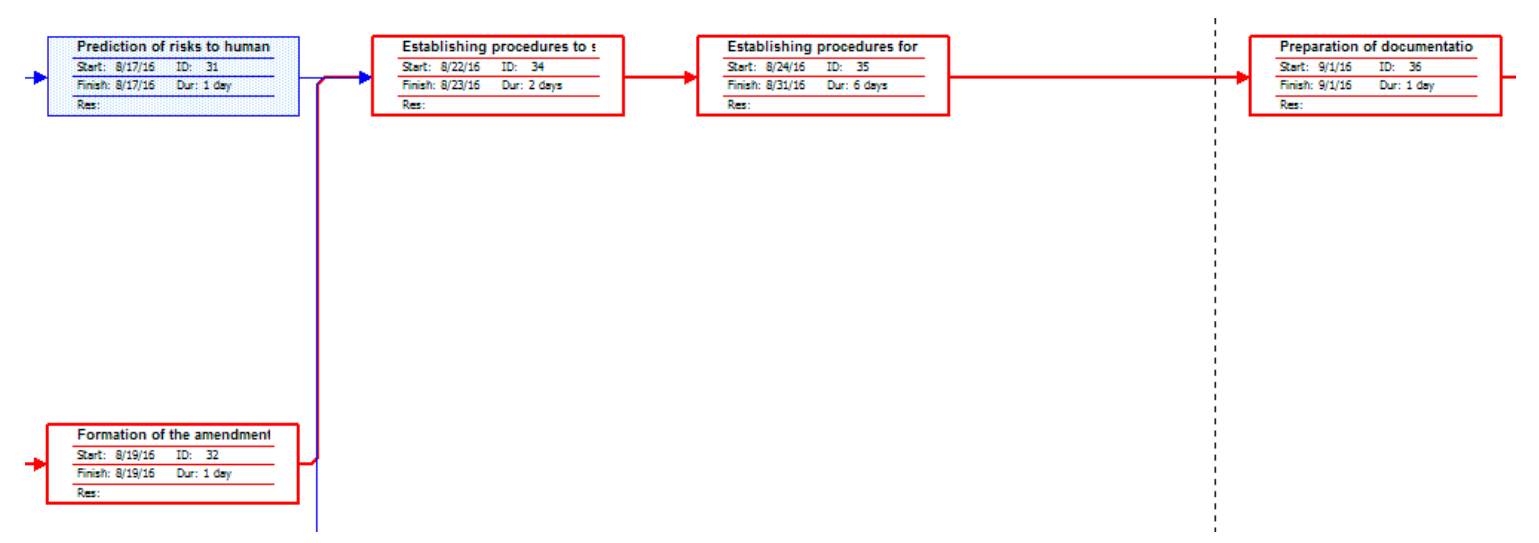

Figure 10. Illustrative part of network diagram of the final phase of the project to improve the environmental protection system in mining and energy complexes.

Besides the environmental quality concern, another reason also stipulates the improvement of environmental protection system. The analyses of health status illustrate the connection between air pollution and the health status of people during short-term and long-term exposure to toxic substances. Dust particles affect the functioning of the cardio-pulmonary system and can cause mortality due to long-term exposure [35], so analyses are carried out in relation to the concentration of pollutants. Studies of the impact of ambient air pollution on human health and mortality reveal an alarming situation. The World Health Organization stresses the need to assess the effects of pollutants on a local and national level, while the associations for waste management emphasize the importance of parallel data analysis on the emission of pollutants and the number of deaths. Time series analyses of air pollution and mortality, from the point of impact of the effects of dust and gaseous products are intended to determine the cause of death and the number of deaths per year and season. Analysis of the risk of mortality in terms of short-term exposure to a higher level of concentration of pollutants, based on the determination of the air pollution index, in order to determine dependence and point to the expected severity of consequences was performed [36]. In the facility "Conveyance and dispatch of coal" in the thermal power plant "Kostolac A" coal dust is the dominant cause of occupational diseases. The analysis of workers' health revealed that $25.69 \%$ workers were suffering from chronic bronchitis. It is necessary to continue further research and determine the influence of gaseous products on the health of workers, but also to analyze the mining and energy complex impact on the health and mortality of the population of the surrounding populated areas [37].

\section{Conclusions}

Increased interest in environmental quality, as well as obligations arising from the EU accession process (particularly derived from the Chapter 27: Environment) impose trend of responsible environmental management. On the other hand, global trends such as the establishment of environmental management system based on ISO standards have similar goals.

Environmental management in mining and energy complexes, based on current legislation, is the foundation for preserving environmental quality and conducting business in keeping with the 
requirements of sustainable development. It is necessary to harmonize the aims and objectives of mining and energy complexes with current regulation in order to protect the organization's reputation, stop the destruction of the environment, avoid paying legally prescribed fines, and prevent a negative reaction from the public. Adjustment of the environmental management system to the amendments of laws in the fields of environmental protection, mining, and energy industry allows a harmonization of environmental aspects, implementation of suitable safety measures, and improved cooperation with the stakeholders.

The global dimension of environmental problems and sustainability, in particular the seriousness of environmental threats due to the operation of the mining and energy complexes of a state, necessitates new methodological approaches in this area. The overcoming of problems arising in the environment as a result of the work of mining and energy complexes should be based on sustainable development principles and should acknowledge the modern European attitudes.

The most important findings are outlined here:

- Prediction and prevention of risk events with adverse effects are significant for a successful concept of environmental quality management. Therefore, it is necessary to develop a model of environmental quality management that would recognize all of the complexity of interactions within mining and energy complexes and the environment.

- Environmental aspects related to interactions within mining and energy complexes should be organized by use of a suitable model (DPSIR, PSR, DSR, FDES, etc.) and ranked. This leads to the formation of a basis of activities that will be organized by the project management process.

- Based on the survey results, we can propose the project management process elaborated through Critical Path Method as a suitable model for the environmental management system improvement in mining and energy complexes.

- Special care should be given to the environmental aspect identification, evaluation, and ranking as to the activities that belong to the critical path.

A key decision-making procedure within the strategic management of a mining and energy complex is the formulation of a plan for environmental management, which enables the implementation of adopted environmental policy, increases the probability of implementing preventive safety measures, and completely excludes deliberate disregard of risk. Consistent and controlled management of mining and energy complexes based on adherence to environmental legislation, detailed assessment of pollutant emission hazards, responsible management of possible accidents, more efficient use of coal as a natural resource, and reduction of environmental risk can help improve the quality of decision-making by the management representatives of the complexes.

The functioning of the management system depends on the financial and technical capabilities, while environmental impact is often neglected. It is necessary to conduct a realistic assessment and harmonize the operations of mining and energy complexes with the principles of sustainable development in a modern manner, with continuous improvement of applied procedures. The academic approach to environmental system modeling in energy industry is based on the use of analytical calculations, statistical analyses, definitions of economic parameters, or assessment of energy losses. System analysis based on a simulation of discrete events (representation of the real state of the environmental system, stochastic parameters) and continuous simulation (representation of changes or operations, with a representation of cause-and-effect relationships between elements) requires the use of modern software tools. Another option is to base the analysis of the impact of the energy sector on environmental quality on considerations of input and output parameters of the environmental system, energy flow, life cycle, ecological footprint, influence of climate change, and reduction of greenhouse gas emissions, which is highly significant for the evaluation of the global impact of the energy sector. Analysis of the impact of coal mining and combustion based on thematic models (analysis of all relevant processes) does not include the impact on all environmental elements, and the use of specialized models does not enable comparison of the results of analyses that are not based 
on the same assumptions and input parameters. An integrated approach requires the creation of functional feedbacks between input-output results of different environmental areas. Even though they provide consistency of assumptions, integrated models do not have priority for the evaluation of energy sector's impact on environmental quality, because they do not consider the observed problems in detail.

Although it is not common in the energy sector, the network planning technique was used in this paper as the foundation on which to improve the environmental management system in mining and energy complexes, as it enables more thorough considerations of the possibilities of implementing preventive safety measures and the adopted environmental policy of mining and energy complexes. Defining an activity plan allows a clear and acceptable definition of goals, tasks, and measures of environmental protection, but also allows an evaluation of the degree of accomplished goals and efficiency of implemented environmental protection measures. The advantage of the presented methodology lies in the comprehensive view of the effects of mining and energy complex operations as well as in the proposal to resolve the existing issues through the realization of management goals and management processes. The goal of implementation is to meet the requirements by standards and stakeholders, while providing conditions for continuous improvement of the environmental management system of mining and energy complexes. The utilization of the proposed management process is aimed at achieving a high degree of realization of environmental goals and of performance of activities planned by the environmental protection department employees regarding the implementation of preventive and corrective safety measures. The advantage of parallel implementation of the control of prescribed procedures and the evaluation of work results lies in the improvement of management activities. The environmental management model contains input elements (necessary for the system to function) and output elements, which depend on the available resources for the realization of planned activities, legislation, standards, and recommendations. The goal is to improve the functioning of the environmental protection system of an organization and to harmonize the activities of employees tasked with implementing safety measures and environmental policy. The proposed procedures can improve the environmental management system for the purpose of adhering to the principles of sustainable development in the energy industry and for the purpose of implementing goals that are of public interest.

Informing the stakeholders about the state of the environment in a simple and clear manner and without concealing the truth is both an ethical and an educational approach of public significance, because citizens are directly involved in energy overconsumption. It is necessary to implement a new concept of sustainable development in energy industry, already accepted by developed countries, according to which the public has a right to be involved in resolving environmental issues. Public involvement in identifying the effects of the operations of mining and energy complexes is very important for the implementation of the principles of sustainable development, because, by choosing healthier living conditions for their children, citizens also opt for improved environmental quality.

The research results show that it is of paramount importance to develop an effective and efficient model for the purposes of environmental management system improvement in mining and energy complexes. The results obtained in this research form a basis for the improvement of the following processes: identification of interdependence aspects in the mining and energy complexes, ecological risk assessment, evaluation of environmental performance level of mining and energy complexes, as well as design of advanced programs of environmental management system improvement in a broader and narrower context and on different spatial and temporal levels. The proposed project management project is based on a realistic assessment of harmful consequences, risk prediction, use of contemporary measures of protection, and changes in ethical attitudes by the leadership. The planned improvement of mining and energy complex environmental protection systems actively contributes to the environmental protection and a more harmonious relationship between the energy sector and sustainable development. 
Acknowledgments: The presented research is a part of the projects "Development of new information and communication technologies, based on advances mathematical methods, with applications in medicine, telecommunications, power systems, protection of natural heritage and education" (III 44006) and "Research and development of energy efficient and environment friendly polygeneration systems based on renewable energy sources utilization" (III 42006), and TR 33039 under the auspices of the Ministry of Education, Science and Technological Development, Republic of Serbia.

Author Contributions: Jelena Malenović Nikolić and Dejan Vasović conceived and designed the structure of the survey; Jelena Malenović Nikolić and Ivica Ristović performed the application of CPM method and analyzed the empirical data; and Stevan Mušicki and Ivana Filipović contributed materials and analysis tools.

Conflicts of Interest: The authors declare no conflict of interest. The founding sponsors had no role in the design of the study; in the collection, analyses, or interpretation of data; in the writing of the manuscript, and in the decision to publish the results.

\section{References}

1. Pokimica, N. National Environmental Approximation Strategy for the Republic of Serbia. Ministry of Environment, Mining and Spatial Planning. Available online: http://www.misp-serbia.rs/wp-content/ uploads/2010/05/EAS-Strategija-ENG-FINAL.pdf (accessed on 31 May 2016).

2. Djukanovic, M. Sustainable Development and the Environment; Elit: Belgrade, Serbia, 1996. (In Serbian)

3. Máca, V.; Melichar, J. The Health Costs of Revised Coal Mining Limits in Northern Bohemia. Energies 2016, 9, 81. [CrossRef]

4. Olías, M.; Nieto, J.M. Background Conditions and Mining Pollution throughout History in the Río Tinto (SW Spain). Environments 2015, 2, 295-316. [CrossRef]

5. World Commission on Environment and Development (Widely Known as Brundtland Commision). Our Common Future; Oxford University Press: Oxford, UK, 1987.

6. Federal Ministry for Development, Science and Environment. The Concept of Sustainable Development-Environment and Development; Federal Ministry for Development, Science and Environment: Belgrade, Serbia, 1997.

7. Miljkovic, M.; Stojkovic, Z. Influence of Metal Ores Surface Extraction to Environmental Factors of the Environment; Faculty of Engineering, Department for mining engineering, University of Belgrade: Bor, Serbia, 1998.

8. Nikolic, J.M. Indicators of Sustainable Thermal Energy Systems Based on Coal Surface Mines. Master's Thesis, Faculty of Occupational Safety, Department for environmental protection, University of Nis, Niš, Serbia, 2007. (In Serbian)

9. Dimitrovski, D.; Djinlev, V.; Dimitrovski, M.; Sapuric, Z. Determining hot carbon monoxide (CO) emissions from passenger vehicles as a parameter for multisectoral decision making process. J. Environ. Prot. Ecol. 2015, 16, 1248-1255.

10. Organisation for Economic Co-Operation and Development (OECD). OECD Environmental Indicators—Development, Measurement and Use; Organisation for Economic Co-Operation and Development (OECD): Paris, France, 2003.

11. Dale, V.H.; Beyeler, S.C. Challenges in the Development and Use of Ecological Indicators. Ecol. Indic. 2001, 1, 3-10. [CrossRef]

12. Zlatanovic, M.; Matejevic, B. Construction Technology and Organization-A Collection of Solved Problems with Excerpts From the Theory; Faculty of Civil Engineering and Architecture, Department for civil engineering, University of Nis: Niš, Serbia, 2012.

13. Ghezloun, A.; Oucher, N.; Chergui, S. Energy policy in the context of sustainable development: Case of Algeria and Tunisia. Energy Procedia 2012, 18, 53-60. [CrossRef]

14. Hall, C.A.S.; Balogh, S.; Murphy, D.J. What is the Minimum EROI that a Sustainable Society Must Have? Energies 2009, 2, 25-47. [CrossRef]

15. Jovovic, A. Assessment of Environmental Impact for the Construction of New Block B3 on the Location of TPP "Kostolac B"; Faculty of Mechanical Engineering and the Faculty of Mining and Geology, University of Belgrade: Belgrade, Serbian, 2013. (In Serbian)

16. Lekic, D.; Jovanovic, M. Reports on the State of the Environment in the Republic of Serbia, for 2012, 2013 and 2014; Ministry of Agriculture and Environment of the Republic of Serbia, Environmental Protection Agency: Belgrade, Serbia, 2015. (In Serbian)

17. Popovic, T. Annual Report on the State of Air Quality in the Republic of Serbia for 2013 and 2014; Environmental Protection Agency: Belgrade, Serbia, 2015. (In Serbian) 
18. Radosavljevic, M.; Drazevic, D. Report on Periodic Measurements of the Emissions of Harmful and Dangerous Substances in the Air by the TPP "Kostolac" in 2009 and 2010; Department of Environment, Mining Institute: Belgrade, Serbia, 2011. (In Serbian)

19. Cvijanovic, D. Internal Documentation of Measurement Results for the Emission of Sulfur Dioxide, Soot and Particulate Matter in TPP "Kostolac"; Thermal Power Plants and Mines Kostolac: Kostolac, Serbia, 2015. (In Serbian)

20. Streimikiene, D.; Sivickas, G. The EU sustainable energy policy indicators framework. Environ. Int. 2008, 34, 1227-1240. [CrossRef] [PubMed]

21. Wang, L.; Xu, L.Y.H.; Song, M. Environmental performance evaluation of Beijing's energy use planning. Energy Policy 2011, 39, 3483-3495. [CrossRef]

22. Bowden, A.R.; Lane, M.R.; Martin, J.H. Triple Bottom Line Risk Management: Enhancing Profit, Environmental Performance, and Community Benefits; John Wiley \& Sons Inc.: Hoboken, NJ, USA, 2001.

23. Janackovic, G.; Savic, S.; Stankovic, M. Selection and ranking of occupational safety indicators based on fuzzy AHP: Case study in road construction companies. S. Afr. J. Ind. Eng. 2013, 24, 175-189. [CrossRef]

24. Lekic, D.; Jovanovic, M. Report on the State of the Environment in the Republic of Serbia in 2014; Ministry of Agriculture and Environment of the Republic of Serbia, Environmental Protection Agency: Belgrade, Serbia, 2015. (In Serbian)

25. Uyterlinde, M.A.; van Arkel, W.G.; Burger, H.; van Dril, A.W.N.; Jeeninga, H.; Kroon, P. Monitoring Energy Efficiency Indicators in The Netherlands in 2000: Dutch Contribution to the Project 'Cross Country Comparison on Energy Efficiency, Phase 6'; Energy Research Centre of the Netherlands: Petten, The Netherlands, 2000.

26. Malenovic Nikolic, J.; Vasovic, D.; Janackovic, G.; Ilic Petkovic, A.; Ilic Krstic, I. Improving the management system of mining and energy complexes based on risk assessment, environmental law and principles of sustainable development. J. Environ. Prot. Ecol. 2016, 17, 1066-1075.

27. Shan, Y.; Goodrum, P.M. Integration of Building Information Modeling and Critical Path Method Schedules to Simulate the Impact of Temperature and Humidity at the Project Level. Buildings 2014, 4, 295-319. [CrossRef]

28. Medved, M.; Ristovic, I.; Roser, J.; Vulic, M. An Overview of Two Years of Continuous Energy Optimization at the Velenje Coal Mine. Energies 2012, 5, 2017-2029. [CrossRef]

29. Szlavik, J.; Csete, M. Climate and Energy Policy in Hungary. Energies 2012, 5, 494-517. [CrossRef]

30. Stefanovic, G.; Skrijelj, H.; Ristovic, I.; Milutinovic, B.; Milosevic, O.; Popovic, S. Sustainable Waste Management Model—Case Study: Novi Pazar. J. Environ. Prot. Ecol. 2014, 15, 1005-1012.

31. International Organization for Standardization. ISO 31000:2009_Principles and Guidelines on Implementation; International Organization for Standardization: Geneva, Switzerland, 2009.

32. International Organization for Standardization. ISO/IEC 31010:2009_Risk Management_Risk Assessment Techniques; International Organization for Standardization: Geneva, Switzerland, 2009.

33. Lerche, I.; Glaesser, W. Environmental Risk Assessment-Quantitative Measures, Anthropogenic Influences, Human Impact; Springer: Berlin/Heidelberg, Germany, 2006.

34. Laurence, D.C. Optimisation of the mine closure process. J. Clean. Prot. 2006, 14, 285-298. [CrossRef]

35. Pope, A.; Burnett, R.; Thun, M.; Calle, E.; Krewski, D.; Kayuhiko, I.; Thurston, G. Lung cancer, cardiopulmonary mortality, and long-term exposure to fine particulate air pollution. J. Am. Med. Assoc. 2002, 287, 1132-1141. [CrossRef]

36. Cizao, R.; Shilu, T. Health effects of ambient air pollution-Recent research development and contemporary methodological challenges. Environ. Health 2008, 7, 56.

37. Rupar, M. The Harmful Consequences of Coal Dust and Uproar of Workers in the Department "Conveyance and Dispatch of Coal" at Thermal Power Station Kostolac; SDITO-Society of Engineers and Technicians of the Municipality of Požarevac: Požarevac, Serbia, 2002. (In Serbian)

(C) 2016 by the authors; licensee MDPI, Basel, Switzerland. This article is an open access article distributed under the terms and conditions of the Creative Commons Attribution (CC-BY) license (http://creativecommons.org/licenses/by/4.0/). 